\title{
The process of death and dying: challenges in nursing care for patients and family members
}

\author{
Processo de morte e morrer: desafios no cuidado de enfermagem ao paciente e família
}

Maria Eduarda Grams Salum ${ }^{1}$, Carolina Kahl ${ }^{1}$, Kamylla Santos da Cunha ${ }^{1}$, Cintia Koerich ${ }^{1}$, Thiago Oliveira dos Santos ${ }^{1}$, Alacoque Lorenzini Erdmann ${ }^{1}$

Objective: to understand the actions and interactions performed by nurses in caring for patients and their family in the process of death and dying. Methods: a qualitative study implementing a theoretical and methodological contribution of Grounded Theory. An individual interview was conducted with 18 participants, divided into three sample groups. Results: weakness in nurses' training regarding the death-dying process, the importance of the nurse-patient bond, family members support, and respect for the grieving process is apparent. As coping strategies, ongoing education, sharing experiences with peers and attachment to spiritual beliefs can be emphasized. Empathy appears as the main challenge, considering the influence of personal and bureaucratic factors. Conclusion: the way nurses respond to the challenges of their professional performance, seeking to build a bond with patients and families, supporting and respecting their process of mourning based on empathy stand out among the actions and interactions performed in care of the patient and family in the process of death and dying.

Descriptors: Death; Attitude to Death; Nursing; Hospitals.

Objetivo: compreender as ações e interações suscitadas por enfermeiros no cuidado ao paciente e família em processo de morte e morrer. Métodos: pesquisa qualitativa com aporte teórico-metodológico da Teoria Fundamentada nos Dados. Foi realizada entrevista individual com 18 participantes, divididos em três grupos amostrais. Resultados: ressalta-se fragilidade na formação do enfermeiro sobre o processo de morte-morrer, importância do vínculo enfermeiro-paciente, apoio aos familiares e respeito ao processo de luto. Como estratégias de enfrentamento, a educação permanente, compartilhamento de experiências com pares e apego às crenças espirituais. A empatia aparece como principal desafio, considerando a influência de fatores pessoais e burocráticos. Conclusão: destaca-se nas ações e interações suscitadas no cuidado ao paciente e família em processo de morte e morrer a maneira como os enfermeiros respondem aos desafios da atuação profissional, buscando construir vínculo com pacientes e familiares, apoiando e respeitando o processo de luto com base na empatia.

Descritores: Morte; Atitude Frente à Morte; Enfermagem; Hospitais.

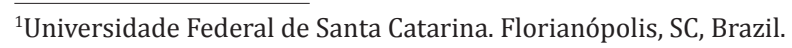

Corresponding author: Maria Eduarda Grams Salum

Avenida Elizeu di Bernardi, 446 - Campinas, CEP: 88101-050. São José, SC, Brazil. E-mail: dudasalum1@gmail.com 


\section{Introduction}

Death is a social construction formed of personal experiences and it has a direct relationship with the cultural aspects in which the individual is inserted. Despite humans being aware that their existence happens within a cycle - birth, development, old age and death - many existential questions about the meaning of life are raised when one experiences the process of death and dying ${ }^{(1-2)}$.

Over the past decades, where death occurs has shifted from the home to the hospital, with a direct impact on the hospital structure since it was developed to provide care that tends to cure disease ${ }^{(3)}$. Health professionals have their training focused on treating and preserving life, in addition to the various ways to recover and promote health. Death can often be seen as a setback in the profession, a reflection of vulnerability and weakness, leading professionals to reflect on the finitude of life, and making it difficult to cope with death ${ }^{(2,4)}$. Providing care for dying patients in the hospital setting is something usual for the health care team, and in particular for the Nursing team, which has the essence of the profession to provide care, give support, assistance and help patients and families who experience the process of death and dying.

In this sense, nurses need to be prepared to provide care for patients in the process of death and dying, since they also require dedication and assistance. However, because it is a fragile moment, the team tends to feel impotent and frustrated, experiencing the loss of patients with whom they had the opportunity to interact during the hospitalization ${ }^{(2)}$.

Although technological advances in health have grown and positively influenced the way people currently die, being a direct reflection of the need for specialized and individualized care to the patient in the process of death and dying, we cannot say that advances in the area of research on providing care to patients experiencing the death and dying process have been equally satisfactory ${ }^{(5)}$.

Considering the complexity and subjectivity of the theme, it is essential to emphasize the importance of studies that allow reflection of the care given to patients and family that experience the process of death and dying; moreover, the challenges faced by health professionals in this process, highlighting the nurse's role as care manager in the various stages of living processes, being healthy, falling ill and dying, aiming at this process to happen in a humanized and comprehensive way. Thus, considering the various aspects that involve and influence nurses' performance regarding the process of death and dying, the present study aimed to understand the actions and interactions performed by nurses in the care of patients and families in the process of death and dying.

\section{Methods}

A qualitative research with the theoretical and methodological contribution of the Grounded Theory, which seeks to understand the reality based on the meanings of the relationships and interactions that a certain context or object has for a person, through a systematic analysis of the data in a way that structure and process are interdependent ${ }^{(6)}$. The study site was a university hospital in the south of Brazil, in the sectors of the adult medical clinic and in the department of a nursing undergraduate course at a public university linked to the hospital, between March and May 2016.

The study sample was comprised of 18 participants divided into three sample groups. The first sample group consisted of nine full-time nurses in medical clinics I and II, whose inclusion criteria were: having already experienced the death process and death of a patient who was under their care, and having at least one year of practice as a nurse in a medical clinic unit. The guiding question for this group was "How do you signify the process of death and dying?" Next, more questions were directed to the participants to advance the research and the understanding of the subject under investigation.

In analysing the interviews of the first group 
we noticed that the nurses associated the difficulties in dealing with the process of death and dying to their undergraduate training. Thus, it was hypothesized that graduation does not prepare nurses to deal with this process. In order to investigate this hypothesis, we chose to create a second sample group.

The second sample group was composed of six undergraduate nursing students from a Federal University in southern Brazil. As inclusion criteria only students enrolled in at least the $7^{\text {th }}$ Phase $(=3.5$ years $)$ of the course who had already experienced the process of death and dying of a patient under their care in the field of training were interviewed. The dialogue started with the following guiding question: Tell me about your experience in caring for patients in the process of death and dying during your undergraduate internship.

Based on the analysis of the interviews of this group we noticed that students have difficulties in dealing with the process of death and dying, despite the presence of a professor the internship field, and that the nursing training process presents gaps regarding this aspect. In this sense, three nursing department professors constituted a third sample group. The inclusion criteria were: being a current and acting professor in the department and having taught classes on the subject or experienced the process of death and dying in the internship with the students. The question that guided and started the interviews was "Tell me how the teaching of the death-dying process is carried out in the nursing undergraduate course." The exclusion criterion adopted for all three sample groups was not having experienced the death and dying process, regardless of the reason.

The data were collected in the place of choice of the participants through open and individual interviews, previously scheduled via telephone contact and made after reading the objective informed consent term and accepting to participate in the research. The interviews were recorded through digital audio voice recording and later transcribed in full for analysis.
As recommended by the method, the comparative analysis process of the data occurred concomitantly to its collection, and was carried out in three stages. In the open coding, the concepts were identified, and then grouped into categories according to their similarities. Then, in the axial coding, the categories and subcategories were related in order to obtain a more in-depth explanation of the data, seeking a clearer and more complete explanation through a systematized analytical comparison process guided by the paradigmatic model of three components of the updated version of this component ${ }^{(6)}$. "Condition" answers questions about why, when and how a given phenomenon happens, designated through an action; "Action-interaction" is the response expressed to such events or situations, as well as how people integrate and act upon meaning; and "consequence" expresses the expected or the actual outcomes and results. Finally, in the integration stage, the categories were interconnected around a central category, in which the phenomenon entitled "Noticing the complexity of care in the process of death and dying" emerged.

Theoretical data saturation was achieved based on repeated information introduced by the participants regarding the phenomenon and the absence of new elements relevant to the research objective. Due to the relevance of the "actions-interactions" component, we chose to deepen its discussion in this study, considering that the integration and meaning of the participants' actions promote understanding of the central phenomenon.

In order to ensure confidentiality and anonymity of the participants, they were represented by the letter G to designate the sample group (G1, G2, G3), and by the letter $\mathrm{E}$ to designate the sequence that the interviews were carried out (E1, E2 ...), thus presented as follows: G1-E2.

The study complied with formal requirements contained in national and international standards for research involving human beings. 


\section{Results}

Based on the relationship among the categories, the phenomenon 'Realizing the complexity of care in the process of death and dying' emerged. The Action-Interactions category entitled 'Unveiling actions and interactions for care in the process of death and dying' presents three subcategories; the first of them concerns actions occurring in the professional practice routine, and the other subcategories refer to coping strategies and challenges faced in the process of death and dying.

The first subcategory "Recognizing interactions with the patient and family in the process of death and dying in practice" emphasizes that in spite of the knowledge obtained during their course or through training on the subject of death, it is only possible to acquire experience and maturity to deal with situations and aspects that involve the process of death and dying with daily practice, taking into account the uniqueness and individuality of human beings experiencing suffering. Although the workload of practical activities during graduation is extensive, most nurses report not having accompanied patients in the process of death and dying during training, which was interpreted as a difficulty to confront and raised their awareness of care behavior in facing this situation. Our profession is something that we learn every day, we will never have complete knowledge, we will never know what our reactions will be according to each situation, it is only by living them, actually living them (G1-E2).

Longer periods of hospitalization promote a creation and strengthening of a bond between patients, family members and nurses, meaning interactions and day-to-day care that are affectionate and fraternal. Such a bond and attentiveness are revealed as positive, since they evidence humanization and comprehensiveness of the care; however, they end up hindering the conduct to be followed in the process of death and dying. The relationship that is formed based on the (everyday) relationship that the professional has with the patient and their family is very important, since the conduct to be taken during the process will be based on this relationship... when we've already had daily contact and a bond, when we've been talking and preparing the family, it is easier to deal with death (G2-E14).

In this sense, extending care to family members is essential, since the family experience the process of death and dying along with the patient. However, on the other hand, the situation may have a negative impact on family relationships and structure, considering that the psycho-spiritual needs of family members in some circumstances exceed those of the patient, and nurses end up providing psycho-emotional support and providing care to everyone. We have to find strength to face this moment of loss, to give support to the family... Nursing professionals are the support for that family member at the time of loss (G1-E4).

Understanding the individuality and uniqueness of each human being is necessary to respect the attitudes and stages of accepting death that can emerge in patients and their families. As a result of the process of death and dying, many feelings and attitudes such as anger, hostility, nervousness and impatience can manifest in patients and their family members, and respecting these reactions is paramount for comprehensive care.

The second subcategory "Seeking strategies for coping with the process of death and dying" highlights the strategies for patient care in the process of death and dying, emphasizing the importance of investing in continuous education, as the experiences during an undergraduation, when opportunistic, are not enough to prepare the professional to deal with the patient and their family in this process. I believe that it was easy for me to deal with the process of death and dying, not because my undergraduation prepared me, but rather because I studied a lot later, I took many courses and training on the subject (G1-E9).

By focusing training toward preserving and maintaining life, nurses perceive the process of death and dying as a barrier, since it represents failure in the objectives of their profession. Thus, dialoguing and sharing feelings between the team enables psycho-emotional support for the professionals, considering that by exchanging experiences and feelings with 
other professionals, nurses can perceive comfort and support, since contextualizing facts and knowledge exchange regarding the subject allow them to accept the process of death and dying. When I get really upset I usually talk to other team members to see what they felt during the process, we unburden ourselves with one another and we share feelings and experiences (G1-E5).

Another strategy highlighted is an attachment to beliefs and religion to face the process of death and dying. Many participants demonstrate that such attachment enables them to find answers to existential questions involving death. My belief helps me a lot to accept and experience death situations because I believe that life does not end here (G1-E9).

The third subcategory "Understanding empathy as a potential challenge for providing care in the process of death and dying" points out the difficulty in putting oneself in another's place, given the individuality of human beings. In this process, the patient's personal experiences and their personality are influencing factors. I see empathy as a permanent challenge, after all, we do not know what pain is until we feel it. Pain is something very subjective and each of us feels it in their own way, which makes "putting yourself in somebody else's place" very difficult (G1-E3).

The association performed by the participants between the patient's process of death and dying and personal situations experienced by them has been pointed out as a barrier, since feelings of remembering a loved one who faced a similar process of death can be remembered. I do not feel prepared to deal with death, since I end up associating some patients with members of my (own) family (G2-E15).

Moreover, due to performing norms and routines (reporting the death when necessary, removing devices, clearing the bed) imposed by the institution, it is important to be careful not to lose sensitivity and humanization in the nursing care, which are fundamental aspects for patient care in the process of death and dying. Often when we become professionals, we acquire a routine, and as soon as death happens we want to provide postmortem care and we (tend to) forget that this is the moment when the family is facing the process of death and dying, and we must devote our attention to that family and the whole context in which they are inserted (G1-E6).

It is important to emphasize the importance of the nurse understanding that the process of death and dying goes far beyond the moment of death, as preparation and support of the patient and their relatives must precede and surpass death itself.

\section{Discussion}

This study aims to investigate data from a single nursing practice scenario, in a specific reality; thus, our findings cannot be generalized. Throughout their professional journey, many nurses are faced with situations in which they need to provide psycho-emotional support to patients experiencing the death process, which provides them the experience and confidence to deal with this process $^{(7)}$. This perspective is in line with the statements of the participants, who emphasize the importance of helpful practice for becoming experienced in the necessary conducts/ actions. However, regarding the approach to patients and families, psychosocial support and assistance in physical comfort and relief can still be studied in the undergraduate program using simulation, thereby potentializing nurses' clinical practice in this regard.

Professionals have a hard time accepting the finitude of life and the impossibility of preventing disease evolution. A study carried out in a hospital showed that day-to-day experience influences changing conceptions and meanings for the care provided to patients in the process of death and dying ${ }^{(8)}$. However, it is essential for clinical practice that nurses understand and keep in mind the birth-to-death life cycle, thus realizing their role in this complex situation ${ }^{(9)}$ that involves several factors, essentially understanding the grieving process.

Experiences that provide assisting patients who are experiencing the process of death and dying have a significant impact on the nurses' trajectory, 
providing them a more realistic view, thus reassessing priorities such as humanization, non-judging and empathy during care(10).

Nurses working in sectors where long hospitalizations are recurrent may feel sensitive to the death of a patient due to the unexpected end of relations established to which the bond is normally constituted ${ }^{(9,}$ ${ }^{11)}$, reinforcing the participants' reports that indicate affectionate connections with assisted patients who experienced the death process.

An international study performed in a hospital highlights the importance of the nurse-patient-family relationship in managing stress arising from situations and procedures, in which the development and implementation of practices that bring family members closer to the health team in the final moments of the patient's life are essential for coping with this $\operatorname{process}^{(12)}$.

Including family members in care is essential for care comprehensiveness and for emphasizing the need for relief from psychological and spiritual sufferings present in the process of death and dying. Thus, it is the nurses' responsibility to prioritize the grieving family's worries and anxiety during the care to prepare them to accept the loss and deal with the pain $^{(13)}$. In this sense, hospital nurses emphasized the importance of including family members in decision-making whenever possible, seeking to satisfy the needs of the family who is experiencing the mourning ${ }^{(14)}$.

According to the participants' reports, personal experiences and the caregivers' personality are factors that influence empathy. An international study performed in a hospital corroborates such reports by stating that due to their singularity, each person manifests themself in a different way before death, perhaps feeling apprehension, anguish and anxiety ${ }^{(15)}$.

The association between the process of death and dying with their personal experiences is a barrier pointed out by the participants and goes against a study that reinforces the idea that the death of another person confronts health professionals to their own fragility and mortality, as well as of their loved ones $^{(16)}$. Furthermore, professionals and patients tend to avoid thinking about death due to the perception that thinking or articulating about it could accelerate the process of death and dying ${ }^{(17)}$.

Comprehensive, sensitive, humanized and gentle care is seen by participants as essential when assisting patients in the process of death and dying. Such a conception is reinforced by a study that signifies the professional-patient relationship as "being with" and not "doing for," leaving aside the care focused on technical tasks and skills, and recognizing the patient as a human being inserted in diverse contexts depending upon bonds and connections ${ }^{(18)}$.

As reported by the participants, investing in continuing education is indispensable, corroborating a study that found that teaching care for patients in the process of death and dying is fragile during professional training, requiring constant training to improve attitudes and skills in psycho-emotional care and support to the patient and family members who are experiencing this process ${ }^{(19)}$.

The participants' reports emphasize the importance of the team talking about their feelings and experiences among them as a form of psychoemotional support, reinforcing the findings of a study that reports the importance of reducing levels of anxiety and fatigue by sharing experiences, thus helping to "normalize" death, seeking a deeper understanding of the meaning of life. Talking about death usually enables learning, encourages respectful treatment of others and favors effective decision-making ${ }^{(10,16)}$.

Beliefs and spiritual practices can often help both the professional and the patient, who together reconstruct the meaning of life when faced with the pain of loss ${ }^{(17)}$. One study points out that spiritual or religious confrontation during mourning is a strategy used to confront the experienced moment, providing inner strength, comfort and consolement ${ }^{(19)}$.

The results of this study can aid in understanding the actions and interactions that involve care 
to the patient and family in the process of death and dying, and to raise discussions about the subject. It presents important support for nurses in this process, which requires complex actions and a demand for training and continuous education such as qualified listening, empathy and interdisciplinary action, along with understanding the mourning process stages, the use of religious belief, ethical care and the exchange of experiences with peers which are all essential for developing these actions.

\section{Conclusion}

Among the actions and interactions performed in caring for patients and their families in the process of death and dying, we can point out the way nurses respond to the challenges of their professional performance. Faced with a weakness in training on the theme, they seek to build a bond with the patient and the family in order to guarantee care humanization and comprehensiveness, supporting and respecting their mourning process based on empathy and using spiritual beliefs and the sharing of experiences with their peers as coping strategies.

\section{Acknowledgements}

To Professor Dr. Laura Cristina da Silva Lisboa de Souza (in memoriam) for her teaching, especially regarding the theme of this study, and inspiration for humanized and welcoming Nursing.

\section{Collaborations}

Salum MEG, Kahl C, Cunha KS and Koerich C contributed to writing the article and to the relevant critical analysis of the content. Oliveira TS contributed to data design, collection, organization and interpretation. Erdmann AL supervised the study and gave approval of the final version to be published.

\section{References}

1. Bandeira D, Cogo SB, Hildebrandt LM, Badke MR. Death and dying in the formation process of nurses from the perspective of nursing professors. Texto Contexto Enferm. 2014; 23(2):400-7. doi: http:// dx.doi.org/10.1590/0104-07072014000660013

2. Arturo PP, Burciaga B, Verónica L, López L, Victoria M, Seañez M, Orvilia A. Resiliencia en el profesional de enfermería que cuida a personas en proceso de morir. Ene [Internet]. 2013 [citado 2017 mar. 12];7(2):2-5. Disponível em: http:// ene-enfermeria.org/ojs/index.php/ENE/article/ viewFile/280/pdf_12

3. Frias C. O cuidar da pessoa em fim de vida como experiência formadora. Av Enferm [Internet]. 2012 [citado 2017 mar. 11];(1):13-22. Disponível em: http://www.scielo.org.co/pdf/aven/v30n1/ v30n1a02.pdf

4. Oliveira PP, Amaral JG, Viegas SMF, Rodrigues AB. Percepção dos profissionais que atuam numa instituição de longa permanência para idosos sobre a morte e o morrer. Ciênc Saúde Coletiva. 2013; 18(9):2635-44. doi: http://dx.doi. org/10.1590/S1413-81232013000900018

5. Bloomer MJ, Endacott R, O'Connor M, Cross W. The 'dis-ease' of dying: Challenges in nursing care of the dying in the acute hospital setting. A qualitative observational study. Palliat Med. 2013; 27(8):757-64. doi: http://dx.doi. org/10.1177/0269216313477176

6. Corbin J, Strauss A. Basics of qualitative research: techniques and procedures for developing Grounded Theory. Los Angeles (CA): SAGE; 2015.

7. Mendes A. Nursing care to facilitate and support 'good' grieving. Br J Nurs. 2015; 24(2):95. doi: http://dx.doi.org/10.12968/bjon.2015.24.2.95

8. Sant'Ana RSV, Santos ER, Menezes TMO, Pereira A, Santana MTBM. A prática assistencial do enfermeiro frente ao processo de morte e morrer: uma revisão integrativa. Rev Enferm UFBE on line [Internet]. 2013 [citado 2017 mar. 11]; 7:91927. Disponível em: http://www.revista.ufpe.br/ revistaenfermagem/index.php/revista/article/ view/3486/pdf_2250 
9. Cardoso DH, Muniz RM, Schwartz E, Arrieira ICO. Hospice care in a hospital setting: the experience of a multidisciplinary team. Texto Contexto Enferm. 2013; 22(4):1134-41. doi: http://dx.doi. org/10.1590/S0104-07072013000400032

10. Veja P, Rodríguez RG, Torres CP, Jarufe EA, Bonilla JM, Díaz CO, Martínez SR. Develando el significado del proceso de duelo em enfermeras(os) pediátricas(os) que se enfrentan a la muerte de un paciente a causa del cáncer. Aquichan. 2013; 13(1):81-91. doi: http://dx.doi.org/10.5294/ aqui.2013.13.1.5

11. Mak YW, Chiang VCL, Chui WT. Experiences and perceptions of nurses caring for dying patients and families in the acute medical admission setting. Int J Palliat Nurs. 2013; 19(9):423-31. doi: http://dx.doi.org/10.12968/ijpn.2013.19.9.423

12. Hogan KA, Bourbonnais FF, Brajtman S, Phillips S, Wilson KG. When someone dies in the emergency department: perspectives of emergency nurses. J Emerg Nurs. 2016; 42(3):207-12. doi: http:// dx.doi.org/10.1016/j.jen.2015.09.003

13. Chan HYL, Lee LH, Chan CWH. The perceptions and experiences of nurses and bereaved families towards bereavement care in an oncology unit. Support Care Cancer. 2013; 21(6):1551-6. doi: http://dx.doi.org/10.1007/s00520-012-1692-4

14. Bloomer MJ, Morphet J, O'Connor M, Lee S, Griffiths D. Nursing care of the family before and after a death in the ICU - an exploratory pilot study. Aust Crit Care. 2013; (26):23-28. doi: http://dx.doi. org/10.1016/j.aucc.2012.01.001
15. Bloomer MJ, Endacott R, O'Connor M, Cross W. The 'dis-ease' of dying: Challenges in nursing care of the dying in the acute hospital setting. A qualitative observational study. Palliat Med. 2013; 27(8):757-64. doi: http://dx.doi. org/10.1177/0269216313477176

16. Gual ME, Sábado JT, Porras DB, Royo CM. The impact of death and dying on nursing students: an exploratory model. J Clin Nurs. 2014; (23):350112. doi: http://dx.doi.org/10.1111/jocn.12602

17. Noble H, Kelly D, Hudson P. Experiences of carers supporting dying renal patients managed without dialysis. J Adv Nurs. 2012; 69(8):1829-39. doi: http://dx.doi.org/10.1111/jan.12049

18. Ek K, Westin L, Prahl C, Österlind J, Susann S, Bergh, Henoch I, Hammarlund K. Death and caring for dying patients: exploring first-year nursing students' descriptive experiences. Int J Palliat Nurs. 2014; 20(10):509-15. doi: http://dx.doi. org/10.12968/ijpn.2014.20.10.509

19. Hawthorne DM, Youngblut JM, Brooten D. Parent spirituality, grief, and mental health at 1 and 3 months after their infant's/child's death in an intensive care unit. J Pediatr Nurs. 2016; (31):73-80. doi: http://dx.doi.org/10.1016/j. pedn.2015.07.008 